\title{
ONE BOAT, TWO CAPTAINS: IMPLICATIONS OF THE 2020 SAMOAN LAND AND TITLES COURT REFORMS FOR CUSTOMARY LAW AND HUMAN RIGHTS
}

\author{
Craig Land
}

\begin{abstract}
Samoa's 2020 Land and Titles Court reforms, which contributed to the Human Rights Protection Party losing support at the April 2021 elections after almost 40 years of government, have recentred attention on the tensions of legal pluralism in the South Pacific. Although Samoa maintains a system of English common law, 81 per cent of Samoan land falls under the traditional matai titles system, giving a central role to the customary Land and Titles Court (LTC). In December 2020, the Samoan parliament passed three Acts - the Constitution Amendment Act 2020, the Land and Titles Act 2020 and the Judicature Act 2020 - establishing the LTC in a parallel court hierarchy with equivalent status to the Samoan Supreme Court and Court of Appeal. This proposal has prompted debate between those favouring incorporation and promotion of Samoan custom over Western legal norms, and others who argue the amendments undermine human rights protections and the rule of law. This article evaluates the effects of these changes on the role and administration of custom in Samoa, contextualising them within broader socio-legal debates around customary legal systems. It first analyses the effect of the three Acts with regard to the bifurcation of the court system, procedural reforms in the LTC hierarchy and the introduction of a judicial guidance clause. This leads into a critical evaluation of these changes, highlighting impacts upon judicial coherence; constitutional human rights; consistency between customary and common law procedures; and resourcing constraints. The article concludes by providing broad options for future reform. It does not focus on issues which have received attention elsewhere, such as the amendments' potential impacts on judicial independence.
\end{abstract}

* LLB (First Class Honours) and BA, The University of Queensland (2020). With thanks to Emeritus Professor Jennifer Corrin for her supervision and guidance in preparing this article. 


\section{INTRODUCTION}

On 24 May 2021, Fiame Naomi Mata'afa was sworn in as Samoa's first female Prime Minister in a tent outside the country's parliament, having been locked out of the building itself. The unusual circumstances of her inauguration were due to the refusal of the caretaker Prime Minister, Tuilaepa Sailele Malielegaoi - leader of the Human Rights Protection Party (HRPP) which had governed Samoa for nearly 40 years - to accept the April 2021 Samoan election results. ${ }^{1}$ The result was a constitutional crisis which has undermined Samoa's reputation as a bastion of political stability in the South Pacific. ${ }^{2}$ Negotiations and court challenges against the validity of the 24 May 2021 swearing in continued until the Samoan Court of Appeal ruled FAST to be the legitimate government of Samoa on 23 July $2021 .^{3}$ On 26 July 2021, Tuilaepa finally conceded the election, bringing the period of instability to an end. ${ }^{4}$

This fallout from the April 2021 elections, as well as being a challenge to Samoan democracy, also represented the culmination of escalating public debate over a series of 2020 reforms restructuring the customary Land and Titles Court (LTC). These reforms were contained in three pieces of legislation - the Constitution Amendment Act 2020 (CAA), the Land and Titles Act 2020 (LTA 2020) and the Judicature Act 2020 (JA) - which passed the Legislative Assembly with amendments on 15 December 2020 and received assent from the Head of State on 5 January 2021 (the three Acts). ${ }^{5}$ The 2020 reforms drew on established academic scholarship analysing the challenges faced by postcolonial states with pluralist legal systems, such as Samoa. ${ }^{6}$ Although the Constitution of Samoa maintains a system of English common law, ${ }^{7} 81$ percent of Samoan land falls

1 See Julia Hollingsworth "The incredible rise of Samoa's first female Prime Minister-elect, and the man still standing in her way" (30 May 2021) CNN <https://edition.cnn.com>; and BBC News "Samoa's first female PM locked out of parliament by losing opponent" (United Kingdom, 25 May 2021) BBC <www.bbc.com>.

2 See for example Iati Iati "Samoa's Price for 25 Years of Political Stability" (2013) 48(4) The Journal of Pacific History 443 at 444; and AH Angelo "'Steady as she goes': the Constitution and the Court of Appeal of Samoa" (2012) 18 New Zealand Association for Comparative Law Yearbook 145 at 164-165.

3 Matai'a Lanuola Tusani T - Ah Tong "Court declares F.A.S.T. Government; impasse over" Samoa Observer (online ed, 23 July 2021) <www.samoaobserver.ws>; and see further Soli Wilson "FAST seeks court clarity to resolve impasse" Samoa Observer (online ed, 20 June 2021) <www.samoaobserver.ws>.

4 Matai'a Lanuola Tusani T - Ah Tong "Tuilaepa concedes, welcomes FAST government" Samoa Observer (online ed, 26 July 2021) <www.samoaobserver.ws>.

5 (15 December) SPD 1067-1070 see "Handsard 2020" Parliament of Samoa <parlemene.ws/handsard-2020/>; and see Constitution Amendment Act 2020 (Samoa), long title; Land and Titles Act 2020 (Samoa), long title; and Judicature Act 2020 (Samoa), long title.

6 See especially Teleiai Lalotoa Mulitalo Ropinisone Silipa Seumanutafa Law Reform in Plural Societies (Springer, 2018)

7 Constitution of the Independent State of Samoa 1960 (Samoan Constitution), art 111 (definition of "law"). 
under the customary matai titles system. ${ }^{8}$ This gives a central role to the LTC, introduced during Samoa's colonial period to adjudicate customary disputes. ${ }^{9}$ The LTC, however, has been criticised for protracted litigation and inadequate resourcing. ${ }^{10}$ Further, a series of constitutional cases previously rendered its jurisdiction subject to enforcement of the Constitution's fundamental rights provisions by the Supreme Court. ${ }^{11}$ This led former Prime Minister Tuilaepa to argue in 2020 that "the Samoan Constitution [is] more protective of the introduced modern principles such as individual rights, as compared to ... the way of life of the Samoan people". ${ }^{12}$ As such, the 2020 reforms sought to establish the LTC in an autonomous court hierarchy with equivalent status to the Supreme Court and Court of Appeal (now the "civil and criminal courts"), thus enabling the growth of an independent customary jurisprudence. ${ }^{13}$

These changes prompted spirited debate regarding the role of customary law in Samoan society. On one side, Tuilaepa and the Samoa Law Reform Commission (SLRC) argued that the reforms represented an essential incorporation and promotion of Samoan custom over Western legal norms. ${ }^{14}$ By contrast, the Samoa Law Society vocally denounced the changes, arguing that they deprived litigants of effective human rights protections and undermined the rule of law. ${ }^{15}$ Samoa-based legal practitioner Fiona Ey has further highlighted the lack of consultation in the initial drafting of the Acts, while raising concerns about the expanded power they grant to the executive to undermine judicial

8 Tu'u'u Ieti Taule'alo, Sooialo David Fong and Patea Malo Setefano Samoan customary lands at the crossroads - options for sustainable management (paper presented to National Environment Forum, 2003) at 2.

9 See Samoa Law Reform Commission Fetuunai Muniao: Lipoti o suesuega (Research Report 1, 2019) at 4-8.

10 See for example Jennifer Corrin "Resolving Land Disputes in Samoa" in Department of Foreign Affairs and Trade Making Land Work Volume Two: Case Studies on customary land and development in the Pacific (Pririon Pty Ltd, Australia, 2008) at 210-212.

11 See Ulisese Aloimaina \& Ors $v$ Land and Titles Court WSSC 4 November 1998 [Aloimaina], cited in Sefo $v$ Land and Titles Court [2000] WSSC 47 and Penaia II v Land and Titles Court [2012] WSCA 6. Please note that, for ease of reference, I have used PacLII references where available.

12 Constitution Amendment Bill 2020 (Samoa) (explanatory memorandum) at [1.5].

13 See Fiona Ey "Samoa's constitutional crisis: Undermining the rule of law" in Georgeou and Hawksley State Responses to COVID-19: a global snapshot at 1 June 2020 (Report, Western Sydney University, 1 June 2020) at $28-29$.

14 Mata'afa Keni Lesa "LTC bills: Masked PM slams "unfounded palagi thinking" Samoa Observer (online ed, Samoa, 28 April 2020) <www.samoaobserver.ws>; and Joyetter Feagaimaali'i "LTC's overhaul began in 2016: Law Reform Commission" Samoa Observer (online ed, Samoa, 2 May 2020) <www.samoaobserver.ws>.

15 Lanuola Tusani Tupufia "UN criticism of LTC changes endorsed by Law Society" Samoa Observer (online ed, Samoa, 6 June 2020) <www.samoaobserver.ws>; Lanuola Tusania Tupufia "LTC Committee's 'misleading' handouts: Law Society" Samoa Observer (online ed, Samoa, 24 July 2020) <www.samoaobserver.ws>; and Lanuola Tusani Tupufia "Delayed decisions and what could happen if LTC bills passed" Samoa Observer (online ed, Samoa, 30 August 2020) <www.samoaobserver.ws>. 
independence by dismissing judges. ${ }^{16}$ She argues that the Acts represent part of a "gradual deconstruction of democracy" in Samoa. ${ }^{17}$ The reforms also prompted Mata'afa - formerly deputy leader of the HRPP - to form FAST as a competing political party. Campaigning on the repeal of the Acts, FAST won a narrow parliamentary majority in the April 2021 elections, ${ }^{18}$ which increased after the Supreme Court ordered seven by-elections due to electoral petitions in HRPP seats. ${ }^{19}$ However, FAST's current majority is still likely insufficient to repeal the legislation in the immediate future, with a two-thirds parliamentary majority needed to enact constitutional changes. ${ }^{20}$

It is beyond the scope of a single article to discuss every implication of the 2020 LTC reforms. Here, I do not focus on rule of law issues already ably described by Ey. ${ }^{21}$ Instead, this article seeks to evaluate the effects of the three Acts on the role and administration of custom in Samoa, placing them in the context of broader socio-legal debates concerning how best to recognise customary legal systems in postcolonial states. Noting that the reforms have now passed into law, it also attempts to analyse how the bifurcated legal system may function in practice. The article is presented in four sections. First, I provide context for the 2020 LTC reforms with an outline of Samoa's pluralist legal system; an explanation of the role of the LTC; and an introduction to major perspectives on more substantive incorporation of custom. I then describe the key changes which the LTC reforms make to the administration of customary law. This leads into a constructive critique of these reforms, highlighting impacts upon judicial coherence; constitutional human rights; consistency between customary and common law procedures; and resourcing constraints. To conclude, I discuss broad alternative reforms which could move the Samoan debate over customary law forward while addressing stakeholder concerns.

16 On these issues, see Ey, above n 13, at 28-29; Anna Dziedzic "Debating constitutional change in Samoa" The Lowy Interpreter (online ed, Australia, 5 May 2020) <www.lowyinstitute.org>; and Letter from the Honourable Michael Kirby and Anne Ramberg (International Bar Association Human Rights Institute CoChairs) to His Excellency Tuilaepa Aiono Sailele Malielegaoi (Prime Minister of Samoa) regarding concerns over major constitutional amendments proposed in the three Acts (19 May 2020) <www.ibanet.org> [IBAHRI Letter].

17 Fiona Ey "Samoa is experiencing a bloodless coup. The Pacific's most stable democracy is in trouble" (14 May 2021) The Guardian <www.theguardian.com>.

18 See Radio New Zealand "Extra seat thrown out, FAST wins Samoa election" (17 May 2021) RNZ <www.rnz.co.nz>.

19 Matai'a Lanuola Tusani T - Ah Tong "Seven by-elections follow petitions" Samoa Observer (online ed, 19 August 2021) <https://www.samoaobserver.ws>.

20 Samoan Constitution, art 109.

21 See Ey, above n 13. 


\section{BACKGROUND}

\section{A Legal Pluralism in Samoa}

In their introduction to South Pacific Property Law, Farran and Paterson juxtapose the increasingly modern infrastructure, jobs and diets available in Pacific Island nations with the customary "traditions, culture and social organisation" that still loom large in everyday life. ${ }^{22}$ Samoa is no exception to this dualism. Samoan society was historically built upon communal subsistence farming and customary governance structures. ${ }^{23}$ Sixty two years of colonial rule, however, have resulted in a constitutionally-enshrined Westminster parliamentary system of government, and increasing individualism fuelled by reforms, such as the introduction of individual leaseholds over customary land. ${ }^{24}$ Custom nonetheless has continuing importance, particularly in villages outside the capital city of Apia. ${ }^{25}$ Indeed, 81 per cent of Samoa's territory is customary land ${ }^{26}$ which cannot be alienated, ${ }^{27}$ recognising close cultural ties and the ongoing impact of colonial landgrabs. ${ }^{28}$ Iati suggests the dual role for custom and a Westminster system of government contributed to Samoa's stability following independence. ${ }^{29}$

While not as diverse as certain Melanesian traditions, the diversity of Samoan custom makes identifying a single, monolithic legal and political system impossible. ${ }^{30}$ Nevertheless, certain common features warrant description. Samoa's 11 traditional administrative districts are divided into over 300 villages, each governed by a village council (fono). ${ }^{31}$ Extended family groups (aiga) are significant within the villages, with each aiga headed by one or more matai who represent the village

22 Sue Farran and Don Paterson South Pacific Property Law (Routledge, 2015) at xxxix.

23 Jennifer Corrin "Land, Law and the Fa'a Samoa" (2008) Lawasia Journal 46 at 49-50; and see generally JW Davidson Samoa 1830 to 1900: The Politics of a Multicultural Community (Oxford University Press, Melbourne, 1970) at 29.

24 J Tim O'Meara "From Corporate to Individual Land Tenure in Western Samoa" in R Gerard Ward and Elizabeth Kingdon (eds) Land, Custom and Practice in the South Pacific (Cambridge University Press, Cambridge, 1995) at 109 and 140-141.

25 Corrin, above n 23, at 47.

26 Taule'alo, Fong and Setefano, above n 8, at 2.

27 Samoan Constitution, art 102.

28 Malama Meleisa and Penelope Schoeffel "Land, Custom and History in Sāmoa" (2015) 5 Journal of Sāmoan Studies 22 at 23-24.

29 Iati, above $\mathrm{n} 2$, at 444 .

30 Mulitalo, above n 6, at 3-5.

31 Corrin, above n 23, at 47. 
and have authority to administer customary land for the common benefit. ${ }^{32}$ Use of customary land is contingent upon continued residence in the village and the rendering of service to the matai, who in return "[see] to the welfare" of each villager. ${ }^{33}$ Succession of matai titles occurs through nomination by the matai or the aiga more broadly. ${ }^{34}$ These customs are given some recognition under Samoan law, with the Village Fono Act 1990 (VFA) validating the customary power of the fono to manage village affairs. ${ }^{35}$ The constitutional definition of "law" further includes, in addition to Acts of Parliament and the received English common law: ${ }^{36}$

any custom or usage which has acquired the force of law in Samoa ... under the provisions of any Act or under a judgment of a Court of competent jurisdiction.

Notably, however, Samoa's Constitution otherwise provided no mechanism to reconcile points of tension between custom and state law. This situation, common to postcolonial states, is usually understood within the framework of "legal pluralism", a theoretical concept referenced in the explanatory memorandum to the Constitution Amendment Bill 2020. ${ }^{37}$ There is no generallyaccepted definition of legal pluralism, but useful for this article's purposes is the distinction between "weak" legal pluralism and "strong" legal pluralism. ${ }^{38}$ Weak legal pluralism sees customary law operating as a "separate or distinct sphere of law", the boundaries and operation of which are defined by state laws. ${ }^{39}$ Relevantly, Corrin notes that legal pluralism in the Pacific context is often reduced to a hierarchical dichotomy between custom and introduced law, with the former dependent on the latter for validity. ${ }^{40}$ Conversely, Woodman defines strong legal pluralism as a situation where custom operates autonomously from state law. ${ }^{41}$ This permits the validity of concurrent sources of legal

32 At 47; and See further Leasiolagi Malama Meleisea "Authority of the Matai Sa'o in Contemporary Samoa: At Home and Abroad" (2018) 8 Journal of Samoan Studies 60.

33 Meleisa and Schoeffel, above n 28, at 29.

34 Ruiping Ye "Torrens and Customary Land Tenure: a case study of the Land Titles Registration Act 2008 of Samoa" (2010) 40 VUWLR 827 at 837.

35 Village Fono Act 1990 (Samoa), s 3(2)-(3).

36 Samoan Constitution, art 111 (definition of "law").

37 Constitution Amendment Bill 2020 (explanatory memorandum) at [1.4].

38 Anne Griffiths "Legal Pluralism" in R Banaka and M Travers (eds) An introduction to law and social theory (Hart, 2002) at 289.

39 At 289

40 Jennifer Corrin "Moving Beyond the Hierarchical Approach to Legal Pluralism in the South Pacific" (2009) 59 Journal of Legal Pluralism 29 at 33-34.

41 Gordon Woodman "Legal Pluralism in Africa: The Implications of State Recognition of Customary Laws Illustrated from the Field of Land Law" [2011] Acta Juridica 35 at 39. 
obligation and is argued to more accurately reflect reality in Pacific societies, where numerous people "see custom as law" regardless of its formal status. ${ }^{42}$

\section{$B$ The Land and Titles Court}

Introduced by the German Colonial government to decide customary land and titles disputes, the LTC is central to contemporary administration of Samoan custom. ${ }^{43}$ The Court has three main functions. Two arise from the Constitution, which grants the LTC jurisdiction over matai titles and customary land. ${ }^{44}$ The third is a power to hear appeals from village fono decisions. ${ }^{45}$ The LTC is often the subject of substantial dissatisfaction in Samoa, due particularly to protracted timeframes for litigation. ${ }^{46}$ A 2016 Special Inquiry Commission into the Court identified several other issues, including favouritism, unprepared judges, judges with connections to particular cases and a litigation culture favouring appeals. ${ }^{47}$ Since this inquiry, attempts have been made to upskill LTC judges and address these problems. ${ }^{48}$ Some writers link the LTC's difficulties, however, to the ballooning number and diversity of matai titles. ${ }^{49} \mathrm{O}$ 'Meara argues the LTC faces an "impossible task" in trying to balance community interests, individual rights and customary law..$^{50}$

For many years, it was unclear whether the Supreme Court had power to judicially review LTC decisions for constitutional compliance, particularly with the Constitution's fundamental rights provisions. Importantly, s 71 of the former Land and Titles Act 1981 (LTA 1981) stated "no decision or order of [the LTC] shall be reviewed or questioned in any other Court". ${ }^{51}$ The Supreme Court first

42 New Zealand Law Commission Converging Currents: Custom and Human Rights in the Pacific (NZLC SP17, 2006) at 41 [Converging Currents].

43 Samoan Constitution, art 103; and see Corrin, above n 23, at 58-63

44 Samoan Constitution, art 103; and see Land and Titles Act 1981 (Samoa) (repealed), s 25.

45 Village Fono Act (Samoa), ss 11(1), (4) and (8).

46 Corrin, above n 10 at 210-212; O'Meara, above n 24, at 145-146; Meleisa and Schoeffel, above n 28, at 33; and Taule'alo, Fong and Setefano, above n 8.

47 Special Inquiry Committee on Land and Titles Court Report of the Special Inquiry Committee (December 2016) at 14 [Special Inquiry Report].

48 Ilia Likou "Land and Titles Court Issues Response" Samoa Observer (online ed, Samoa, 29 January 2017) $<w w w . s a m o a o b s e r v e r . w s>$.

49 Matori Yamamoto "Urbanisation of the Chiefly System: Multiplication and Role Differentiation of Titles in Western Samoa" (1994) 103(2) Journal of Polynesian Society 171 at 181-183, and see Tuimaleali'lfano, Morgan "Titular Disputes and National Leadership in Samoa" (1998) 33(1) The Journal of Pacific History 91 at 94 and 103 .

50 O'Meara, above n 24 at 145; and see further Corrin, above n 23, at 64-65.

51 Land and Titles Act 1981 (repealed), s 71. 
considered this provision in Alaelua $v$ Land and Titles Court, ${ }^{52}$ where an LTC decision was challenged on natural justice grounds. The applicant argued that non-compliance with the Constitution rendered the LTC's decision a nullity. Thus, the s 71 ouster clause could not apply because there was no "decision" to review. ${ }^{53}$

The Supreme Court refused to exercise judicial review over the LTC, departing from English authorities such as Anisminic $v$ The Foreign Corporation. ${ }^{54}$ The judgment set out six principles regarding the LTC's jurisdiction: 55

(1) The LTC is a unique court, but not an inferior court.

(2) The LTC has exclusive jurisdiction over Samoan titles and customary land.

(3) The LTC has its own appeal procedure.

(4) The LTC governs a legal system different and separate to that administered by the Supreme Court.

(5) The LTC is in certain respects equal to the Supreme Court.

(6) The LTC is the supreme authority for Samoan custom.

In the Court's view, it followed from these principles that s 71 was effective to preclude judicial review by the Supreme Court. ${ }^{56}$ In reaching this conclusion, the Court emphasised that "Samoa has two legal systems," each with its own institutions. ${ }^{57}$

The subsequent case of Aloimaina $v$ Land and Titles Court reached a different conclusion. ${ }^{58}$ Aloimaina involved a challenge to a banishment order issued by the LTC, asserting a breach of the right to a fair trial in art 9(1) of the Constitution. ${ }^{59}$ In reaching his decision, Young $\mathrm{J}$ expressly overruled the reasoning in Alaelua.$^{60}$ Noting the LTC's similarity to other specialist inferior courts, such as the New Zealand Māori Land Court, ${ }^{61}$ he concluded that the LTC was, like these others, an inferior court subject to judicial review by the Supreme Court on fundamental rights grounds. ${ }^{62}$ This

52 Alaelua $v$ Land and Titles Court (1992) 3 WSLR 507 (SC Apia) [Alaelua].

53 At 515

54 Anisminic Ltd v Foreign Compensation Commission [1969] 1 All ER 208 (HL), cited in Alaelua at 516.

55 Alaelua, above n 52, at 519 .

56 At 520

57 At 516 .

58 Aloimaina, above $\mathrm{n} 11$.

59 See Samoan Constitution, art 9(1)-(2), cited in Aloimaina, above n 11, at 8.

60 Aloimaina, above n 11, at 13 .

61 At 14.

62 At 13 . 
did not affect its "primacy ... on questions of land, chiefly titles and custom". ${ }^{63}$ The decision in Aloimaina therefore implicitly reinforced the importance of art 2 of the Constitution, ${ }^{64}$ which declares the Constitution to be the supreme law of Samoa, and voids any laws (including LTC decisions) inconsistent with its provisions. Aloimaina has subsequently been cited as authority for the Supreme Court's judicial review powers over the LTC. ${ }^{65}$

These cases contextualise the 2020 LTC reforms. The explanatory memorandum for one bill implicitly expresses dissatisfaction with the decision in Aloimaina, asking "In a court room, why are individual rights more powerful than Village Fono decisions? [...] Because the Constitution says so". ${ }^{66}$ Importantly, though, the Supreme Court has repeatedly cautioned against the "wrongful and technical" use of judicial review as a remedy. ${ }^{67}$ Lavea $v$ Kerslake ${ }^{68}$ established that in order to seek judicial review, an applicant must first "persuade the court that proceedings in the [LTC] would not provide an adequate remedy". ${ }^{69}$ This is consistent with Young J's reasoning in Aloimaina, where his Honour highlighted that the LTC "is not in any sense 'inferior' in the way commonly referred to in a non-legal sense". ${ }^{70}$

\section{Samoan Perspectives on Legal Pluralism}

While the explanatory memorandum cited above identifies one viewpoint, the 2020 LTC reforms have brought diverse perspectives to the fore on the role of customary law in Samoa. It is consequently helpful to summarise common arguments for and against reform.

\section{Arguments for reform}

The case supporting an increased role for custom is made most strongly by Telei'ai Lalotoa Mulitalo, the Executive Director of the SLRC. Mulitalo's research, focusing on consultations with key Samoan legal actors, suggests an "overwhelming desire" for greater acknowledgement of custom within the Samoan legal system. ${ }^{71}$ Such findings are consistent with work from the New Zealand Law

63 At 13 .

64 Samoan Constitution, art 2(1)-(2).

65 See for example Sefo v Land and Titles Court, above n 11; and Land and Titles Court v Lautogia [2018] WSCA 4.

66 Constitution Amendment Bill 2020 (explanatory memorandum) at [1.5]

67 Rimoni v President of the Land and Titles Court [2011] WSSC 88 at [16].

68 Lavea v Kerslake [2015] WSCA 3.

69 At [39].

70 Aloimaina, above n 11, at 14.

71 Mulitalo, above n 6, at 58-59. See also Samoa Law Reform Commission Fetuunai Muniao: Lipoti o suesuega, above $\mathrm{n} 9$. 
Commission (NZLC), which notes that a large proportion of people in Pacific Island nations view both custom and introduced law as valid. ${ }^{72}$ Mulitalo contends that, in the absence of mechanisms to determine where custom should be applied, common law-trained legal professionals default to applying common law doctrines without considering customary practice. ${ }^{73}$ This builds on work from Corrin, who points to the role of "the language of the common law" in establishing a legal hierarchy that marginalises customary language and principles. ${ }^{74}$ In light of this, Mulitalo is sceptical of custom's capacity to be codified into statute, suggesting written codification "cannot capture a full account" of the diverse and flexible customary traditions across different villages. ${ }^{75}$

A key assumption underpinning Mulitalo's argument is that the Constitution and common law embody "different philosophies" to customary law. ${ }^{76}$ She argues custom is based on communalism and a strict hierarchy, seeking to preserve "peace and harmony in the village". ${ }^{77}$ On this view, the individual rights expressed in the Constitution are inapplicable, foreign, and have limited relevance for many Samoans, ${ }^{78}$ with Mulitalo pointing to a case where a village fono enforced a banishment order despite its revocation by the LTC. ${ }^{79}$ Even writers who do not consider individual rights and Samoan custom to be in tension, such as Samoan Ombudsman Maiava Iulai Toma, accept there is a broad perception of conceptual conflict. ${ }^{80}$ To some degree, however, this may reflect demographic differences. Huffer and So'o note a divide within Samoa between individuals holding matai titles, who favour promoting customary law over current constitutional norms; and urban Samoan professionals who, having often spent time working in common/civil law jurisdictions, are more suspicious of this. ${ }^{81}$

72 Converging Currents, above n 42, at 41-42.

73 Mulitalo, above n 7 at 71-72; but see Angelo, above n 2, at 164-165.

74 Jennifer Corrin "Customary Land and the Language of the Common Law" (2008) 37(4) Common Law World Review 305 at 331 .

75 Mulitalo, above n 6, at 62, and see 63-65.

76 At 50.

77 At 50; but see Elise Huffer and Asofou So'o "Consensus versus dissent: Democracy, pluralism and governance in Samoa" (2003) 44(3) Asia Pacific Viewpoint 281 at 291.

78 Mulitalo, above n 6, at 53-55.

79 At 1-2, describing Leota Leuluaialii Ituau Ale et al v Alii \& Faipule of Solosolo Land and Titles Court of Samoa LC.11469 P2, 17 February 2012.

80 Office of the Ombudsman and National Human Rights Institution State of Human Rights Report: Summary (Government Printer, Samoan Ombudsman, 2015) at 1.

81 Elise Huffer and Asofou So'o "Beyond Governance in Sāmoa: Understanding Sāmoan Political Thought" (2005) 17(2) The Contemporary Pacific 311 at 326-327. 


\section{Arguments against reform}

Opponents to the above argument suggest it significantly understates the already-existing role of Samoan customary law. Notably, in a submission on the LTC reforms, the Samoan judiciary rejected the proposition that the civil and criminal courts "control and interfere" with the LTC. ${ }^{82}$ The submission highlighted the Supreme Court's conservative use of its judicial review powers and emphasized the Court's inability to review the merits of LTC decisions. ${ }^{83}$ Long-standing jurisprudence supports this: in Penaia II $v$ Land and Titles Court, ${ }^{84}$ the Court was "reluctant to intervene" in LTC disputes unless necessary to enforce the Constitution, given the LTC's specific expertise on Samoan custom. ${ }^{85}$ Where judicial review is successful, the Supreme Court ordinarily remits matters back to the LTC for reconsideration on the customary merits. ${ }^{86}$ More broadly, when the Court has dealt with disputes impacting on customary land, such as cases challenging historic landgrabs, ${ }^{87}$ it has relied on evidence from matai and historians to draw conclusions on customary issues. ${ }^{88}$ This perspective also strongly refutes any suggestion that Samoan lawyers and judges, many of whom hold matai titles, are "not sufficiently Samoan". 89

Regarding a clash between custom and individual rights, many writers argue the values of Samoan custom are consistent with universal rights, even if specific practices are in tension with the concept. Certainly, there are "hard issues" where customary practice is difficult to reconcile with human rights. ${ }^{90}$ Many articles identify "patriarchal institutions" in Pacific custom and advocate for greater legal protections for Pacific women, particularly around domestic violence. ${ }^{91}$ Religious freedom is

82 Joyetter Feagaimaali'i "Judges caution Government about judicial overhaul" Samoa Observer (online ed, Samoa, 12 April 2020) <www.samoaobserver.ws> at [26].

83 At [27]-[29].

84 Penaia II $v$ Land and Titles Court, above $\mathrm{n} 11$.

85 At [17].

86 Feagaimaali'i, above n 82, at [28]; and see for example Esekia $v$ Land and Titles Court [2017] WSSC 145 at [44].

87 See for example Alii and Faipule of Laulii v Trustees of the Estate of Jacob Helg [2011] WSSC 48 [Laulii v Helg].

88 At [31]-[32].

89 Ey, above n 13, at 29.

90 Converging Currents, above n 42 , at 83.

91 Safua Akeli Amaama "Navigating CEDAW obligations and 'custom' in Samoa" (2018) Journal of South Pacific Law 95 at 103-106; See also Jennifer Corrin Care and Kenneth Brown "Conflict in Melanesia: Customary Law and the Rights of Women" in Corrin Care "The Development of South Pacific Islands Jurisprudence: The Status of and the Relationship between Introduced Law and Customary Law in Small Island Countries of the South Pacific" (PhD Thesis, Griffith University, 2002). 
another commonly-raised issue: Samoa is predominantly Christian, and non-Christians or nonmainstream Christians often experience discrimination. ${ }^{92}$ Nevertheless, Tofa suggests protecting individuals from "grave injustice" does not detract from Samoa's communal values and outlook. ${ }^{93}$ Huffer and So'o identify several concepts underpinning customary practice, including 'autasi (consensus), alofa (love/compassion), fa'aloalo (respect) and mamalu (dignity). ${ }^{94}$ From these values, Vaa derives a Samoan concept of human rights, with every citizen obtaining both rights and responsibilities in their role as a suli (heir) to Samoan culture. ${ }^{95}$ In this respect, Lawson cautions against a "tradition-versus-modern (Western) dichotomy", which is liable to conceal the diversity of local views on concepts such as democracy and human rights. ${ }^{96}$

\section{THE 2020 LTC REFORMS}

As already noted, the 2020 LTC reforms are contained in three Acts passed by the Samoan Legislative Assembly on 15 December 2020 and assented to by the Head of State on 5 January $2021 .{ }^{97}$ The JA commenced upon assent, ${ }^{98}$ while the other statutes had commenced by notice by 15 April $2021 .{ }^{99}$ In this section, I describe key amendments these Acts make to the role of customary law in Samoa: namely, the establishment of an independent customary court hierarchy; ${ }^{100}$ changes to LTC procedure; and the introduction of a judicial guidance clause for the civil and criminal courts.

92 See for example Sefo v Land and Titles Court, above n 11; and further Jennifer Corrin "A green stick or a fresh stick?: Locating customary penalties in the post-colonial era" (2006) 6(1) Oxford University Commonwealth Law Journal 27 at 39.

93 Maiava Iulai Toma "Submission to Parliamentary Select Committee for Health and Social Services, Internal Affairs, Community and Social Development regarding the Land and Titles Bill 2020, Constitution Amendment Bill 2020 and Judicature Ordinance Bill 2020" (14 May 2020) at 3 [Ombudsman's Submission].

94 Huffer and So'o, above n 81, at 312.

95 Unasa LF Vaa "Samoan Custom and Human Rights: an indigenous view" (2009) 40 VUWLR 237 at 241.

96 Stephanie Lawson Tradition versus Democracy in the South Pacific: Fiji, Tonga and Western Samoa (Cambridge University Press, Melbourne, 1996) at 163.

97 Constitution Amendment Act 2020; Judicature Act 2020; and Land and Titles Act 2020.

98 Judicature Act, s 1(2).

99 Matai'a Lanuola Tusani T-Ah Tong "Three new LTC judges sworn in" Samoa Observer (online ed, Samoa, 15 April 2021) <www.samoaobserver.ws>; and see Constitution Amendment Act, s 1(2); and Land and Titles Act 2020, s 1(2)-(3).

100 "Customary courts" is a short hand referring to the Land and Titles First Court, Land and Titles High Court, and Land and Titles Court of Appeal and Review. 
Reference will be made to the draft form of each Act where these previous versions are instructive as to the intention or effect of a provision. ${ }^{101}$

\section{A Establishing an Independent LTC Hierarchy}

The unprecedented effect of the LTC reforms is to establish the LTC within an autonomous court hierarchy. Section 7 of the CAA creates a new appellate structure for the LTC under pt IX of the Constitution. ${ }^{102}$ This involves renaming the current LTC to the Land and Titles First Court (LTFC), ${ }^{103}$ as well as introducing a Land and Titles High Court (LTHC) ${ }^{104}$ and a Land and Titles Court of Appeal and Review (LTCAR). ${ }^{105}$ Leave is needed to appeal to the two higher courts. ${ }^{106}$ Judges in these courts will be Samoan legal practitioners who have rendered matai service to their village for a set number of years (with some exceptions, discussed below). ${ }^{107}$ The LTC hierarchy will continue to hear appeals from village fono decisions. ${ }^{108}$

The sources of law applicable to the courts in this new hierarchy are Samoan custom and usage and the law relating thereto, as well as any statutes "expressed to apply to the court[s]". ${ }^{109}$ Conversely, s 57 of the LTA 2020 states that decisions of the civil and criminal courts - including past decisions concerning subjects within the new hierarchy's jurisdiction - are not binding on the new customary courts. ${ }^{110}$ Section 57 departs from the position in the draft bills, which stated that "the English common law and equity ... does not apply in the Land and Titles Court". ${ }^{111}$ In the absence of this prohibition, s 57 seemingly leaves open the possibility that relevant decisions of other courts, including Samoan courts, could be persuasive to the new customary courts, though they are not a binding source of law. Ultimately, however, decisions will be made "in accordance with what [the court] considers to be fair and just". ${ }^{112}$

101 Constitution Amendment Bill 2020 (Samoa); Judicature Bill 2020 (Samoa); Land and Titles Bill 2020 (Samoa).

102 Constitution Amendment Act, s 7 .

103 Section 7, inserting art 104A.

104 Section 7, inserting art 104B.

105 Section 7, inserting art 104C.

106 Land and Titles Act 2020, ss 39-44 and 46-48.

107 Constitution Amendment Act, s 7, inserting art 104D(1), but see s 7 inserting art 104C(2).

108 Village Fono Act, s 11.

109 Constitution Amendment Act, s 7, inserting arts 104A(6), 104B(6) and 104C(6).

110 Land and Titles Act 2020, s 57.

111 Constitution Amendment Bill, cl 7, inserting arts 104A(8), 104B(6), and 104C(6).

112 Constitution Amendment Act, s 7, inserting arts 104A(7), 104B(6), 104C(6). 
To establish the new court hierarchy's independence, the CAA excludes pt IX of the Constitution from the jurisdiction of the civil and criminal courts ${ }^{113}$ and abolishes the current right of appeal from the LTC to the Supreme Court on fundamental rights grounds, ${ }^{114}$ effectively restoring the position in Alaelua. The Act instead vests the LTCAR with its own, broad judicial review powers which, ${ }^{115}$ according to the Samoan government, are intended to permit both the Supreme Court and the LTCAR to enforce the fundamental rights. ${ }^{116}$ Certain commentators, however, have interpreted the CAA as excluding fundamental rights from customary matters altogether. ${ }^{117}$ Favouring the government's interpretation is the broad jurisdiction of the three customary courts, which includes anything "necessary to administer the laws under this Part IX". ${ }^{118}$ Article 104A(6)(c) further supports the official interpretation by requiring the LTFC to apply "this Constitution" without limitation. ${ }^{119}$ Understandable confusion has arisen, however, from art 4(2) of the Constitution, which vests power to enforce fundamental rights in the Supreme Court but does not mention the LTCAR. ${ }^{120}$ Article $104 \mathrm{C}(9)$ also contradicts the government's view, permitting matters in lower customary courts to be removed to the LTCAR only where there is a question of constitutional interpretation "under this Part" (being pt IX). ${ }^{121}$

It is unclear whether this ambiguity and others throughout the legislation are the result of unsatisfactory drafting or merely inadequate translation from Samoan to English. This article adopts the government's interpretation of the CAA to guide its analysis, noting it is consistent with the Explanatory Memorandum's intention to avoid "removing ... current rights and freedoms". ${ }^{22}$ At the outset, however, it must be noted that even following amendments, the Act is ambiguous on this point and would benefit from clearer drafting.

113 Section 4, amending arts 70 and 75 .

114 Section 2, amending art 4(1).

115 Section 7, inserting arts 104C(6)(b) and 104C(7)(b).

116 Funefe'ai Dikaiosune Atoa Tamaalii "Press Release: Office of the Attorney-General \& Samoa Law Reform Commission" (press release, 13 June 2020).

117 See for example Ombudsman's Submission, above n 93, at 9-10.

118 Constitution Amendment Act, s 7, inserting arts 104A(4)(b), 104B(5)(b) and 104C(5)(b).

119 Section 7, inserting art 104A(6)(c).

120 Samoan Constitution, art 4(2).

121 Constitution Amendment Act, s 7, inserting art 104C(9).

122 Constitution Amendment Bill (explanatory memorandum) at [1.6]. 


\section{B Amendments to LTC Procedure}

Perhaps seeking to address current criticisms of the LTC, the Acts enact sweeping procedural changes within the new court hierarchy. Most notably, the LTA 2020 (which repeals its 1981 predecessor) ${ }^{123}$ implements strict time limits for each stage of proceedings, to address issues of unreasonable delay. Time limits are imposed both on parties - with a 40-day time limit to request leave to appeal and a 30-day limit for respondents to subsequently file a response ${ }^{124}$ - and on the Court itself, with requirements to hear appeals within two months and then deliver judgments within three. ${ }^{125}$ A catch-all provision bars unreasonable delay of matters through adjournment. ${ }^{126}$ In addition, the LTA 2020 requires a suite of new procedural rules to be written, including rules governing categories of relevant evidence; a right of response for all parties to proceedings; an obligation to follow relevant precedent; and an obligation to only consider matters in evidence before the Court. ${ }^{127}$ The new courts are also required to give reasons in open court for all matters. ${ }^{128}$

The highest court, the LTCAR, has certain specific features. Unlike the lower courts, the LTCAR is made up of one retired judge, one current Supreme Court judge, one LTC President or retired Deputy President, and a Samoan lawyer eligible to be a Supreme Court judge. ${ }^{129}$ Moreover, s 64 of the LTA 2020 lifts the longstanding ban on lawyers appearing before the LTC, but only for LTCAR proceedings. ${ }^{130}$ These additional procedural requirements reflect the LTCAR's general importance, including its judicial review powers.

\section{Judicial Guidance Clause}

Aside from jurisdictional questions, the only substantial alteration to procedure in the civil and criminal courts is the introduction of a judicial guidance clause. The CAA substitutes a new art 71 of the Constitution, which states "customs may be taken into account in all courts under this Part". ${ }^{131}$ With limited guidance provided on how the clause should operate, art 71 raises two key questions.

123 Land and Titles Act 2020, s 66.

124 Sections 40(2)-(3); and see further ss 40(3), 44(3) and 47(2)-(3).

125 Sections 41(5)(d), 48(5)(c) and 54; and see further ss 41(4), 48(4).

126 Section 36(3).

127 Section 62(4)(a)-(b).

128 Section 54 .

129 Constitution Amendment Act, s 7, inserting art 104C(2).

130 Land and Titles Act 2020, s 64.

131 Constitution Amendment Act, s 4, amending art 71. 


\section{How should courts identify custom?}

Although the LTA 2020 defines "custom and usage" for the purposes of the customary court hierarchy, ${ }^{132}$ no such definition is provided for the civil and criminal courts. Further, the judicial guidance clause does not state how custom should be identified or proven. Given the civil and criminal courts' lack of jurisdiction over laws administered under pt IX of the Constitution, ${ }^{133}$ including "customs and usage matters relating to matai titles and customary lands", ${ }^{134}$ there is a question whether these customs are excluded from the scope of the judicial guidance clause. A more substantial ambiguity, however, is whether custom must be established as a matter of fact or a matter of law. If custom is a matter of fact, then evidence needs to be brought to support the custom's existence. Conversely, if custom is a matter of law, it need not be supported by evidence. ${ }^{135}$

The Constitution's structure assists with this question. Recall that the constitutional definition of "law" includes any custom or part thereof "under the provisions of any Act or under a judgment of a Court of competent jurisdiction". ${ }^{136}$ Recall further that courts in the new LTC hierarchy must give reasons for judgment and follow their own relevant precedents. ${ }^{137}$ Given the new hierarchy will have "special individual jurisdiction" over Samoan custom, ${ }^{138}$ giving the courts within it "competent jurisdiction" in this respect, ${ }^{139}$ it follows that a custom stated in an LTC judgment is consistent with the constitutional definition of law. The same reasoning applies to any customs provided for by statute, providing another avenue for custom to be established as a matter of law. In the absence of these sources, however, the Supreme Court will need to rely on factual evidence to establish a custom's existence. This is consistent with the approach in cases such as Alii and Faipule of Laulii v Trustees of the Estate of Helg, ${ }^{140}$ where the Court used scholarship and expert witnesses to ascertain the existence of customary practices.

132 Land and Titles Act 2020, s 2(1) (definition of "custom and usage" or "Samoan custom or usage").

133 Section 4, arts 70 and 75 .

134 Section 6, art 104(2).

135 Jennifer Corrin "Accommodating legal pluralism in Pacific Courts: problems of proof of customary law" (2011) 15 International Journal of Evidence and Proof 1 at 2-3; see further Jean G Zorn and Jennifer Corrin Care Proving Customary Law in the Common Law Courts of the South Pacific (Occasional Paper 2, The British Institute of International and Comparative Law, London, 2002) at 4-5; and Converging Currents, above $n$ 42, at $185-190$.

136 Samoan Constitution, art 111 (definition of "law").

137 Land and Titles Act 2020, ss 55 and 64(4)(a)(iii).

138 Constitution Amendment Act, s 6, amending art 104(2).

139 Samoan Constitution, art 111 (definition of "law").

140 Laulii v Helg, above n 87. 


\section{When and how may custom be "taken into account"?}

Article 71 also provides limited guidance on how courts may "[take] into account" custom; other than that custom remains "subject to the provisions of the Constitution". ${ }^{141}$ Notably, the section was amended during the legislative process, with the draft Bill instead stating that custom "must be taken into account" by the civil and criminal courts. ${ }^{142}$ This shift in language suggests the intention is not for custom to be considered universally. Further, the phrase "take into account" contrasts with the LTC's obligation to "apply" customs under s 104A of the CAA, ${ }^{143}$ implying that the Supreme Court need not apply custom whenever it is considered. In other areas of Samoan law, such as criminal sentencing or assessing general damages, courts "take into account" factors when deciding how to exercise a discretion or resolve an ambiguity. ${ }^{144}$

The draft clause was influenced by art XI, s 11 of the Constitution of the Federated States of Micronesia, ${ }^{145}$ which requires decisions to be "consistent with [the] Constitution, Micronesian customs and traditions, and the social and geographical configuration of Micronesia". ${ }^{146}$ In Semens v Continental Airlines Inc, ${ }^{147}$ the Micronesian Supreme Court held that this clause imposes an obligation to consider custom as a source of law even if it is not raised by parties to a proceeding. ${ }^{148}$ For example, the clause has been used to prevent the strict and unfair application of civil procedure rules to Indigenous applicants. ${ }^{149}$ However, the Court in Wito Clan v United Church of Christ ${ }^{150}$ noted there is rarely "clear, uncontradicted evidence of custom on point," and therefore consideration of custom proceeds on a case-by-case basis. ${ }^{151}$ Where "activities which gave rise to [a] lawsuit are not of a local or traditional nature", there is no obligation to exhaustively search for applicable customary principles. ${ }^{152}$

141 Constitution Amendment Act, s 4, amending art 71.

142 Constitution Amendment Bill 2020, cl 4, amending art 72 (emphasis added).

143 Constitution Amendment Act, s 7, inserting art 104A(6)(a).

144 See for example Katopau v Samoa Breweries Ltd [2000] WSSC 36 at [54]-[56]; and Police v Tulaga [2006] WSSC 51

145 See Samoa Law Reform Commission, above n 71, at [3.2]-[3.3].

146 Constitution of the Federated States of Micronesia [Micronesian Constitution], art XI, s 11.

147 Benter Semens v Continental Airlines Inc \& Others [1985] FMSC 3, (1985) 2 FSM Intrm 131 [Semens].

148 At 140.

149 Hadley $v$ Board of Trustees [1985] FMPSC 2, (1985) 3 FSM Intrm 15 at 16.

150 Wito Clan v United Church of Christ [1993] FMSC 4, (1993) 6 FSM Intrm 129.

151 At 132 .

152 Semens, above n 147, at 140. 
Whereas the Micronesian Constitution mandates consistency with custom, the Samoan clause in its final form is permissive. This brings it closer to legislative provisions in other jurisdictions. For example, sch 1 of the Laws of Kiribati Act 1989 permits custom to be enforced and pleaded in common law courts where it is consistent with legislation and the Constitution. ${ }^{153}$ Both the Underlying Law Act 2000 (Papua New Guinea, discussed below) ${ }^{154}$ and the Customs Recognition Act 2000 (Solomon Islands) ${ }^{155}$ similarly provide guidelines on when and how courts may consider customs. All these examples provide greater detail than art 71 on how custom relates to other legal sources, and when it should be taken into account. ${ }^{156}$ The Samoan provision is worded broadly enough to permit the courts to consider custom in any case where it is pleaded, and possibly even where it is not (subject to legislative and constitutional fair trial obligations). ${ }^{157}$ However, given that the provision is permissive rather than mandatory, it is unclear to what degree a failure to consider custom could ground an appeal. It is also unclear when a customary rule might prevail over other sources of law.

In the absence of this guidance, it is questionable whether the amended clause will substantively increase the role of Samoan custom. Certainly, the clause permits consideration of custom as a source of law. Nonetheless, Mulitalo argues that the permissive legislation cited above has "largely struggled to fulfil [its] obligations", and prefers a mandatory provision such as the Micronesian example. ${ }^{158} \mathrm{~A}$ permissive clause similarly fails to address her concern that common-law trained judges will default to applying common-law norms without considering custom unless obligated to do otherwise. ${ }^{159}$ Consequently, while the clause's role will be defined through use in practice, amendments to the proposed mandatory language in art 71 have likely neutered the clause's potential impact.

\section{EVALUATING THE LTC REFORMS}

The amendments to LTC procedure show that certain aspects of the proposed reforms legitimately improve the administration of customary law in Samoa. The area of greatest controversy, however, has been the bifurcation of Samoa's legal system into two separate court hierarchies. This proposal is inconsistent with the 2016 Special Inquiry into the LTC, which recommended maintaining the Supreme Court's current judicial review function. ${ }^{160}$ As Toma writes, it effectively moves the existing

153 Laws of Kiribati Act 1989 (Kiribati), sch 1.

154 Underlying Law Act 2000 (Papua New Guinea), ss 3-5.

155 Customs Recognition Act 2000 (Solomon Islands), s 6.

156 But see Constitution Amendment Act, s 4, amending art 71.

157 See Samoan Constitution, art 9; and Land and Titles Act, s 62(4)(a)(ii).

158 Mulitalo, above n 6, at 135

159 At $71-72$.

160 Special Inquiry Report, above n 47, at 30-31. 
statutory architecture of the LTC into the Constitution while simultaneously "[placing] that structure and its deliberations outside of regular Constitutional surveillance". ${ }^{161}$ In this section, I discuss four consequences of this: legal incoherence between the two court hierarchies; potential human rights breaches; the imposition of common law procedures on the administration of custom; and an increased caseload for an already under-resourced LTC structure.

\section{A Legal Coherence}

The removal of a single apex court in the Samoan court hierarchy poses significant challenges for legal coherence. Legal coherence's desirability is derived from the rule of law, one aspect of which is that citizens should be able to identify the applicable law in any given situation in order to comply. ${ }^{162}$ A jurisdiction with plural legal systems, such as Samoa or federal systems such as Australia, faces greater complications in accomplishing this. Normally, however, an apex court balances legal coherence with legal pluralism by resolving conflicting interpretations of legal sources and removing doubt over which legal system applies in a given situation. ${ }^{163}$ The bifurcation of the court system under the LTC reforms, however, removes such an apex. Although the civil and criminal courts remain the default court hierarchy in the majority of cases, ${ }^{164}$ a limited number of cases concerning customary land and titles (or village fono appeals) will now proceed through a separate LTC hierarchy with its own unreviewable legal standards and procedures.

Theoretically, two independent, coherent court hierarchies without an apex can be established through careful drafting. For example, while not expressly excluded, ${ }^{165}$ English common law is not listed as a valid source of law for the new court hierarchy under art $104 \mathrm{~A}(6) .{ }^{166}$ This removes the possibility that the Supreme Court and the LTC could issue different, authoritative interpretations of a single common law precedent. In practice, though, this drafting process would be extremely difficult, and the absence of an apex court removes any way to resolve conflicts if they arise. In this context, the Acts raise several coherence problems, particularly in the application of statute, the Constitution and custom across the two hierarchies.

161 Ombudsman's Submission, above n 93, at 2.

162 John Finnis Natural Law and Natural Rights (Oxford University Press, Oxford, 1980) at 270-271; and Lon Fuller The Morality of Law (New York University Press, New York, 1964) at 39.

163 Mark Tushnet "Judicial Accountability in a Comparative Perspective" in N Bamforth and P Leyland (eds) Accountability in a Contemporary Constitution (Oxford University Press, 2013) 57 at 57-58.

164 See Constitution Amendment Act s 4, amending art 70(1).

165 But see Constitution Amendment Bill 2020, cl 7, inserting art 104A(8).

166 Constitution Amendment Act, s 7, inserting art 104A(6). 


\section{Statute}

The Acts create a risk of conflicting interpretations of the same statute. Article 104A(6)(c) of the CAA requires the new LTCs to apply "any ... enactment expressed to apply to the [courts]". ${ }^{167}$ In theory, such a statute should be excluded from the jurisdiction of the civil and criminal courts, as a "law administered" under pt IX. ${ }^{168}$ In practice, several existing statutes, such as the Land Titles Registration Act 2008, will fall for consideration by both courts. ${ }^{169}$ In this situation, the Supreme Court would interpret the statute in line with the Acts Interpretation Act 2015. There is ambiguity whether the customary courts can apply this Act, which applies to "all Acts" including those considered by the LTC, ${ }^{170}$ but is not "expressed to apply to the court" as art $104 \mathrm{~A}(6)(\mathrm{c})$ requires. ${ }^{171}$ If the Act does not apply, the court would interpret the statute consistent with custom. ${ }^{172}$ Even if, as seems more likely, the Act does apply, legal history is littered with cases where judges have arrived at different results using identical principles of interpretation. Indeed, s 57 of the LTA 2020 expressly states that civil and criminal court jurisprudence is not binding upon the new court hierarchy and provides no guidance on this issue in the reverse direction. ${ }^{173}$ With no apex court, then, conflicting interpretations could not be resolved.

\section{Constitution}

The CAA's intention to permit both court hierarchies to judicially review matters on fundamental rights grounds invites conflicting interpretations of Samoa's supreme law. Human rights provisions, by nature, are expressed at a high level of generality and depend significantly on interpretation. ${ }^{174} \mathrm{~A}$ clear example of this in the Samoan Constitution is the allowance for "reasonable restrictions" on several fundamental rights, ${ }^{175}$ which is meaningless until interpreted in context. Whereas the civil and criminal courts would understand "reasonable restrictions" in line with extensive common law jurisprudence on the meaning of "reasonableness", ${ }^{176}$ the new LTC hierarchy would have to interpret

167 Section 7, inserting art 104A(6)(c).

168 Section 4, amending arts 70 and 75.

169 Land Titles Registration Act 2008 (Samoa), s 86; but see Land and Titles Act 2020, s 9(3).

170 Acts Interpretation Act 2015 (Samoa), s 2(1)(a).

171 Constitution Amendment Act, s 7, inserting art 104A(6)(c).

172 Section 7, inserting art 104A(6)(a)-(b).

173 Land and Titles Act 2020, s 57.

174 Jack Tsen-Ta Lee "Interpreting bills of rights: the value of a comparative approach" (2007) 5 International Journal of Constitutional Law 122 at 129.

175 Samoan Constitution, arts 11(2), and 13(2)-(3).

176 See Jennifer Corrin and Don Paterson Introduction to South Pacific Law (3rd edition, Palgrave MacMillan, Victoria, 2011) at 116-117. 
the concept from a customary perspective. ${ }^{177}$ Little assistance is provided as to how the customary courts should go about this, barring a vague aspirational statement in the explanatory memorandum that village fono decisions should be "more powerful" than individual rights. ${ }^{178}$ While the LTA 2020 leaves open the possibility that the new court hierarchy may follow persuasive precedents of the Supreme Court or Court of Appeal on these issues, there is no obligation for them to do so. ${ }^{179}$ The lack of clarity on this point risks both hierarchies issuing conflicting rulings on Samoa's supreme law, which would undermine both legal coherence and Samoa's human rights obligations (discussed below).

\section{Custom}

Conflicting decisions between the two court hierarchies seem most likely in relation to custom. As already discussed, the introduction of a judicial guidance clause means the civil and criminal Courts will be able to consider custom in some fashion. ${ }^{180}$ In doing so, they could use LTC judgments to identify applicable customary principles. Where the LTC has not issued guidance on a point, however, custom would have to be established as a matter of fact in the civil and criminal courts. These findings are non-binding on the LTC hierarchy, ${ }^{181}$ and may subsequently clash with customs identified by the LTC.

A further issue relates to the potential for the customary courts to expand the notion of "custom" and therefore their limited jurisdiction. Contrary to commentary from the Samoa Law Society, this is unlikely to arise in relation to the LTC's power to declare land to be "customary land" and consequently within its jurisdiction. ${ }^{182}$ Under s 9 of the LTA 2020, the LTC may only declare land to be customary land with the consent of any parties asserting freehold title to the land, or alternatively where any claims for freehold title have been rejected by the independent Land Titles Investigation Commission. ${ }^{183}$ The Court therefore cannot expand its jurisdiction without external approval.

However, there is a larger problem in relation to the powers of customary punishment administered by village fono. ${ }^{184}$ The VFA validates the broad customary powers of the fono to

177 Constitution Amendment Act, s 7, inserting art 104A(6)(a).

178 Constitution Amendment Bill 2020 (explanatory memorandum) at [1.5].

179 Land and Titles Act 2020, s 57.

180 Constitution Amendment Act, s 4, amending art 71.

181 Land and Titles Act 2020, s 57.

182 Samoa Observer "What LTC bills mean for customary and freehold land" (Facebook, 26 April 2020 , 00:00:00-00:01:30) <www.facebook.com>.

183 Land and Titles Act 2020, s 9(3)-(5).

184 See Village Fono Act, s 6. 
manage village affairs. ${ }^{185}$ This includes a power to impose fines, community service or banishment, "without limiting the power ... to impose punishments for village misconduct": 186 a provision which, on its face, suggests the fono's power of punishment is virtually unlimited. ${ }^{187}$ Where a person is convicted of an offence for which a fono has already imposed a penalty, s 8 of the VFA requires that penalty to be taken into account in mitigation of any sentence imposed by the criminal courts. ${ }^{188}$ However, there is no mechanism provided for determining whether the fono or the court should have criminal jurisdiction: a villager could not be sure which system they will be punished under. With the bifurcation of the courts, there is also now no clear forum in which to determine these jurisdictional issues. ${ }^{189}$ Given the vague terms in which the power of the fono to impose punishment is expressed, then, the Acts create the potential for fono to significantly confuse the operation of criminal law in Samoa.

\section{B Human Rights}

Many stakeholders, from the Samoa Law Society to the United Nations, have criticised the exclusion of the Supreme Court's capacity to judicially review LTC decisions on human rights grounds. ${ }^{190}$ Some of these arguments proceed from a conclusion that the three Acts prevent the LTCAR from applying the constitutional rights provisions altogether. ${ }^{191}$ As already discussed, such a conclusion is an understandable but erroneous interpretation of ambiguous drafting. Legitimate questions nonetheless arise concerning whether customary interpretations of the fundamental rights provisions by the LTCAR and others will result in human rights breaches for Samoan citizens. Indeed, it is curious at the outset, given former Prime Minister Tuilaepa's assertions that individual rights cannot be reconciled with Samoan custom, ${ }^{192}$ that the new system entrenches consideration of those same rights (by at least one Supreme Court judge) into the customary courts. ${ }^{193}$ Noting this, this section analyses three human rights criticisms arising from the new Acts, relating to Samoa's

185 Section 3(2)-(3).

186 Section 6.

187 The position is more complex than this: see below at Part IV(B)(2) relating to human rights.

188 Village Fono Act, s 8.

189 Neither court hierarchy can deal with matters within the purview of the other: Constitution Amendment Act, s 4, arts 70 and 75; and s 6, art 104(1).

190 See IBAHRI Letter, above n 16; Ey, above n 13; and Lanuola Tusani Tupufia "UN criticism of LTC changes endorsed by Law Society" Samoa Observer (online ed, Samoa, 6 June 2020) <www.samoaobserver.ws>.

191 See for example Ombudsman's Submission, above n 93.

192 See Mata'afa, above n 14.

193 Constitution Amendment Act, s 7, inserting art 104C(2). 
obligations under human rights treaties; potential abuses of power by village fono; and the right to a fair trial.

\section{International treaty obligations}

As a preliminary point, Petra Butler has suggested the bifurcated court system violates Samoa's obligations under the International Covenant on Civil and Political Rights (ICCPR). ${ }^{194}$ The Samoan government ratified the ICCPR in $2008,{ }^{195}$ and must therefore guarantee the rights under the Convention to all citizens "without distinction of any kind". ${ }^{196}$ The proposed structure, with two court hierarchies enforcing separate interpretations of human rights, contravenes this requirement. Where the court hierarchies diverge on the human rights standards they apply, they will create a distinction between litigants in the two court hierarchies. The reforms further breach art 26 of the ICCPR, which requires signatories to guarantee all citizens "equal protection of the law". ${ }^{197}$ The ICCPR is a notoriously slippery instrument to enforce, ${ }^{198}$ but the reforms nonetheless expose Samoa to significant international backlash for failing to comply with its treaty commitments.

\section{Powers of the village fono}

More concretely, the Acts create the potential for village fono to abuse their power. As already discussed, $\mathrm{s} 6$ of the VFA vests a power of customary punishment in village fono that, on its face, is expressed in unlimited terms. ${ }^{199}$ In Leituala $v$ Mauga, this power was interpreted narrowly by the Supreme Court. ${ }^{200}$ Leituala concerned a banishment order, where local residents are excluded (sometimes permanently) from their village. ${ }^{201}$ While the Court in that case upheld the validity of banishment as a customary punishment, it stated that banishment could only be ordered by the LTC (subject to judicial review by the Supreme Court), effectively limiting the fono's powers. ${ }^{202}$ In doing so, the Court expressed concern that banishment, if not exercised sparingly and in accordance with

194 Sapeer Mayron "LTC Bill would breach human rights: lawyer" Samoa Observer (online ed, Samoa, 29 April 2020) <www.samoaobserver.ws>.

195 International Covenant on Civil and Political Rights 999 UNTS 171 (opened for signature 19 December 1966, entered into force 23 March 1976).

196 Article 2.

197 Article 26.

198 See Yvonne Dutton "Commitment to international human rights treaties: the role of enforcement mechanisms" (2012) 34(1) University of Pennsylvania Journal of International Law 1 at 2-3.

199 Village Fono Act, s 6.

200 Leituala v Mauga [2004] WSSC 9. See discussion in Corrin, above n 92, especially at 43-46.

201 See Taamale v Attorney General [1995] WSCA 12.

202 Leituala, above n 200, at [26]. 
law, would conflict with the constitutional freedom of speech, movement and assembly. ${ }^{203}$ This was because the Court was not satisfied that "fair and equal treatment of village residents" could be guaranteed by the fono given their lack of formal procedural safeguards. ${ }^{204}$ Subsequently, the Village Fono Amendment Act 2017 expressly restored the fono's power to order banishment, ${ }^{205}$ subject to a new legislative procedure ensuring a minimum of procedural fairness. ${ }^{206}$ This new procedure mirrors the constitution's fair trial rights by allowing an accused to hear the case against them, respond to it and have their response considered. ${ }^{207}$ More generally, the Act empowers fono to keep records of investigations into village misconduct, although such record-keeping is not mandated. ${ }^{208}$ In that sense, although Leituala is not binding on the new customary courts, ${ }^{209}$ the 2017 amendments go some way to mitigating against unjust outcomes in banishment cases.

After the 2020 constitutional changes, however, fresh concerns arise around the impact of customary interpretations of constitutional rights on these issues. The LTA 2020 defines "custom and usage" as referring to both customs and usages "accepted by the people of Samoa in general" and those "accepted as being in force in respect of a particular place". ${ }^{210}$ Further, the HRPP noted during parliamentary debate on the legislation that "communal rights" arising from Samoan custom could not be sourced in legislation and would be identified by the LTC on a case-by-case basis. ${ }^{211}$ This leaves the customary content of the constitution's fundamental rights vague and open to interpretation. Notably, it would be open for the new customary courts to view fono decisions as "reasonable restrictions" on religious freedom or free movement to ensure "public order, health and morals". ${ }^{212}$ Equally, however, this view might not be adopted - the only interpretive guidance within the legislative materials is an aspirational suggestion that fono decisions may now have greater weight vis-à-vis individual rights. ${ }^{213}$ It is therefore important to emphasise that the problem is not the idea of

203 At [30].

204 At [25].

205 Village Fono Amendment Act 2017 (Samoa), s 7(b).

206 Section 7(c).

207 Compare Samoan Constitution, art 9, and Village Fono Amendment Act, s 7(c). See also Village Fono Amendment Bill 2016 (Samoa) (explanatory memorandum) at "Clause 7".

208 Village Fono Amendment Act, ss 4-5.

209 Land and Title Act 2020, s 57.

210 Section 2(1) (definition of "custom and usage" or "Samoan custom and usage").

211 (15 December 2020) SPD at 966-7 per Hon Gatoloaifaana Amataga Alesana-Gidlow.

212 Samoan Constitution, arts 11(2) and 13(2)-(3).

213 Constitution Amendment Bill 2020 (explanatory memorandum) at [1.5]. 
synthesising customary law and constitutional rights of itself, but rather the lack of guidance on how this difficult interpretive exercise will be implemented without sacrificing checks and balances.

This is problematic because, as has been argued since original debates on the VFA, "misuse of power" by fono has historically been an issue in certain villages. ${ }^{214}$ Judicial review cases concerning fono decisions have had higher success rates than other LTC judicial reviews. ${ }^{215}$ In Sefo v Land and Titles Court ${ }^{216}$ and Lafaiallii v Attorney General, ${ }^{217}$ the Supreme Court found that a decision to ban non-mainstream Christian groups from a village breached the constitutional freedom of religion. A 2012 SLRC inquiry into the VFA found that scales of customary punishment differed in proportionality from village to village. ${ }^{218}$ Some sources even attribute the so-called "Lona incident", where a man was shot dead in his village, to the increased powers of the fono under the VFA. ${ }^{219}$ The 2017 reforms to the VFA guaranteed procedural fairness in banishment cases, but merely encouraged (without mandating) record-keeping in other misconduct cases. ${ }^{220}$ Notably, the 2017 reforms did not adopt a number of further proposals from the 2012 SLRC inquiry, including a uniform scale of punishments for village misconduct and a division between instances of minor and major misconduct. ${ }^{221}$ Certainly, progress has been made in balancing autonomy for customary leaders with avoiding abuses of power. Where a fono asserts authority outside the bounds of its customary power, a right of appeal to the LTFC and its appellate courts should ensure checks and balances. ${ }^{222}$ However, the CAA's lack of guidance on how to interpret constitutional rights from a customary perspective is concerning, creating space to legally validate abuses at the fono level.

214 Samoa Law Reform Commission Village Fono Act 1990 (R 09/12, June 2012) at [1.1]-[1.3]. See also Lawson, above $\mathrm{n}$ 96, at 139 .

215 Samoa Law Reform Commission Fetuunai Muniao: Lipoti o suesuega, above n 9, at 45, citing Tuivaiti v Faamalaga [1980] WSSC 2; Sefo v Land and Titles Court [2000] WSSC 47; Lafaialii v Attorney General [2003] WSSC 8 .

216 Sefo v Land and Titles Court, above n 11.

217 Lafaialii v Attorney General [2003] WSSC 8.

218 Samoa Law Reform Commission, above n 214, at 24.

219 Le'apai Lau Asofou So'o "Governance and rendered services" in Samoa National Human Development Report (2006) at 160. See further Lawson, above n 96, at 155-156.

220 Village Fono Amendment Act, ss 4 and 7(c).

221 Samoa Law Reform Commission, above n 214, at 13-14 and 24-25.

222 Village Fono Act 1990, s 11. 


\section{Right to a fair trial}

In contrast to the above concerns, it is not clear that the CAA substantively deprives litigants of their right to a fair trial as some critics suggest. ${ }^{223}$ Criticisms on this basis have largely relied on current procedural deficiencies in the LTC such as inordinately delayed proceedings ${ }^{224}$ and bias, ${ }^{225}$ including several cases where the presiding judge was related to one of the parties. ${ }^{226}$ Notably, though, most judicial review cases of LTC matters on fair trial grounds have been struck out for failing to disclose a cause of action. ${ }^{227}$ Further, the LTA 2020's broad procedural reforms alleviate most concerns, subjecting the customary courts to clear procedural limitations. The new requirements for a right of reply, ${ }^{228}$ the delivery of reasons in open court, ${ }^{229}$ rights against unreasonable delay, ${ }^{230}$ an obligation to only consider matters in evidence before the court, ${ }^{231}$ and the introduction of binding precedent ${ }^{232}$ implement in substance many key elements of a fair trial. Where these procedural safeguards are breached, the appellate structure allows procedural deficiencies to be corrected. There remain gaps: in particular, there does not appear to be any equivalent to the common law rule against bias. Similarly, the absence of legal representation in the LTFC and LTHC may limit the capacity of litigants to fully ventilate procedural fairness issues in those Courts. ${ }^{233}$ Crucially, though, the LTCAR may still enforce art 9 (which, unlike some of the other rights provisions, is expressed in relatively concrete terms) in the most egregious cases. ${ }^{234}$ It is therefore difficult to see where unfairness could

223 See especially Ey, above n 13.

224 Corrin, above n 10 at 212; and Special Inquiry Report, above n 47, at 23.

225 Special Inquiry Report, above n 47, at 22.

226 See Land and Titles Court v Lautogia, above n 65; Lauvai v Land and Titles Court [2010] WSSC 185; and Leleua v Land and Titles Court [2009] WSSC 123.

227 Samoa Law Reform Commission Fetuunai Muniao: Lipoti o suesuega, above n 9, at 15; see for example Peniamina $v$ Land and Titles Court [2004] WSSC 12; Rimoni v President of the Land and Titles Court, above n 67; Penaia v Land and Titles Court [2011] WSSC 84; Sagoto v Land and Titles Court [2011] WSSC 79; Mapuilesua $v$ Land and Titles Court [2011] WSSC 131; Tanielu v Apellate Divison of the Land and Titles Court [2016] WSSC 113; and Akeimo v Appellate Division of the Land and Titles Court [2017] WSSC 36.

228 Land and Titles Act 2020, s 62(4)(a)(i).

229 Sections 54-55.

230 Section 36(3).

231 Section 62(4)(a)(ii).

232 Section 62(4)(a)(iii).

233 But see s 64.

234 Samoan Constitution, art 9. 
arise, with even the Samoan Human Rights Ombudsman supporting the procedural reforms to the LTC (although not the broader restructuring of the court system). ${ }^{235}$

\section{LTC Procedure in Relation to Customary Law}

In common law courts, scholars often note that strict procedural requirements are inconsistent with the flexible, largely oral nature of customary law. ${ }^{236}$ Consequently, the introduction of rules governing categories of relevant evidence, a doctrine of precedent and a role for lawyers in the LTC hierarchy, while they will all likely improve efficiency and consistency in the courts, raise some concerns for the administration of custom in Samoa. It should be noted, though, that the issues discussed in this section are all avoidable through careful drafting of procedural rules.

\section{Evidence}

Section 62 of the LTA 2020 only requires the making of rules for "categories of relevant evidence permitted to be presented before the court", with no other guidelines. ${ }^{237}$ Certainly, some limitations on evidence will be beneficial for the LTC hierarchy. The 2016 Special Inquiry favoured new rules for cross-examination by judges, noting that irrelevant questions, offensive language, and questions "directed as if a criminal investigation were being conducted" are currently common. ${ }^{238}$ However, the NZLC recommends against "strict evidential requirements for proof of Pacific custom", particularly concerning hearsay and opinion. ${ }^{239}$ Samoan customary law is a largely oral tradition passed from one person to another, ${ }^{240}$ which is fundamentally inconsistent with the hearsay rule's requirement for firsthand accounts (even noting the rule's many exceptions). Further, parties in the LTC hierarchy will be largely unrepresented (see below), ${ }^{241}$ making complex evidential requirements an unnecessary hindrance.

Other specialist courts, such as the Island Courts in Vanuatu and the Australian Administrative Appeals Tribunal, limit evidential requirements to a broad test of relevance, ${ }^{242}$ although tribunal members in the latter may determine the weight of particular evidence. A notable contrast is the Māori Land Court in New Zealand, which is subject to the Evidence Act 2006 (although notably not the

235 Ombudsman's Submission, above n 93 at 5.

236 Corrin, above n 135, at 8.

237 Land and Titles Act 2020, s 63(4)(b).

238 Special Inquiry Report, above n 47, at 22 and 28.

239 Converging Currents, above n 42, at 197.

240 Corrin, above n 135, at 8.

241 See Land and Titles Act 2020, s 64.

242 Casey v Repatriation Commission [1995] FCA 847, (1995) 39 ALD 34 at 38; and Vanuatu Island Courts Act (Consolidated Edition) 2006, s 25. 
hearsay rule), ${ }^{243}$ but also permits legal representation. ${ }^{244}$ Relaxed evidence rules for custom have also been adopted in common/civil law courts in several jurisdictions, including (non-exhaustively) Australia, Papua New Guinea, Tuvalu and Kiribati. ${ }^{245}$ While limiting categories of admissible evidence can improve fairness and efficiency in LTC proceedings, these categories should be drafted broadly and avoid complex limitations which will bog proceedings down in legal technicality.

\section{Precedent}

The LTA 2020 specifically requires the LTC hierarchy to follow its own relevant precedents. ${ }^{246}$ This combats perceived unfairness, with the 2016 Special Inquiry noting "frustration amongst the witnesses [regarding] inconsistent rulings". ${ }^{247}$ However, the NZLC notes that "in finding what the current customary law is, the use of prior cases may be the least certain method". ${ }^{248}$ Different villages apply custom in different ways and principles often develop significantly outside the bounds of formal courtroom proceedings. A judge in American Samoa notes that "establishing a binding precedent based on the shifting sands of custom and tradition handed down through the centuries by word of mouth is a chancy undertaking". ${ }^{249}$ As such, other jurisdictions, such as Papua New Guinea, do not apply judicial precedent in village courts. ${ }^{250}$

Noting the above, the NZLC recommends a relaxed doctrine of precedent for custom, focusing on customary values rather than specific rules. ${ }^{251}$ This addresses concerns by Meleisa and Schoeffel that the lack of any clear definition of custom leads to decisions based on "undefined, possibly arbitrary, and often contrary" rules. ${ }^{252}$ To avoid potential downsides for this approach, the LTA 2020 allows for the customary courts to depart from strict application of procedural rules to avoid "inequitable or inconvenient" results. ${ }^{253}$ Ultimately, however, the specific drafting of procedural rules will be key to balancing procedural fairness with customary realities.

243 Evidence Amendment Act (No 2) 1980 (NZ), s 13.

244 Te Ture Whenua Māori Act 1993 (NZ), s 70.

245 Evidence Act 1995 (Cth) ss 72 and 78A; Underlying Law Act 2000 (PNG) s 16; Laws of Tuvalu Act 1987 (Tuvalu), sch 1, [1]; and Laws of Kiribati Act 1989, sch 1, [1].

246 Land and Titles Act 2020, s 62(4)(a)(iii).

247 Special Inquiry Report, above n 47, at 18.

248 Converging Currents, above n 42, at 187.

249 Kaliopa v Silao [1981] ASHC 1 at n 1.

250 Constitution of the Independent State of Papua New Guinea, sch 2.8(2).

251 Converging Currents, above n 42, at 188.

252 Meleisa and Schoeffel, above n 28, at 33.

253 Land and Titles Act 2020, s 62(5). 


\section{Role of lawyers}

Finally, concerns have been expressed that permitting lawyers to argue cases before the LTC will focus the court on technical legal arguments rather than custom. ${ }^{254}$ Given the specialised nature of LTC cases, Samoa Law Society president Leaitaualesa Komisi Koria argues that matai "knowledgeable in genealogies and customs" should argue proceedings in the customary courts. ${ }^{255}$ This is consistent with Corrin's research, which suggests lawyers can impose a common law "legal culture" on customary bodies that is not appropriate to resolve customary disputes. ${ }^{256}$ Koria's view is not universal within the Law Society, however; another representative has argued that lawyers will serve to "[narrow] issues and [prevent] irrelevant evidence being put forward", improving LTC efficiency. ${ }^{257}$

The latter perspective should be preferred in this context, given that the LTC reforms maintain a very limited role for lawyers in the LTC system. Indeed, the final version of the LTA 2020 removes the long-standing right of litigants to have solicitors prepare documents for LTC proceedings. ${ }^{258}$ The only addition is that lawyers may now argue proceedings before the peak appellate court, the LTCAR. ${ }^{259}$ While Samoan legal culture favours appeals, the grounds for appeal to the LTCAR are limited to cases of great legal or cultural significance. ${ }^{260}$ Bringing in lawyers for a small number of important appeals therefore balances Koria's concerns with the need for significant cases to be fully ventilated. One important caveat, however, is the possibility of substantial "inequities in dispute resolution proceedings" where only one party is represented, given Samoa's limited legal aid capacity. $^{261}$

\section{Resource Constraints}

The final, but most material, problem for the proposed system may be the resources of the LTC itself. Criticisms of the LTC's lengthy delays in decision-making reflect long-term under-resourcing

\footnotetext{
254 Corrin, above n 10, at 211.

255 Samoa Observer "Matai eligibility and strain on Lands and Titles Court" (Facebook, 28 April 2020, 00:02:4000:03:30) <www.facebook.com>.

256 Corrin, above $\mathrm{n} 74$, at 331 .

257 At 211 .

258 Land and Titles Act 1981 (repealed), s 44. But see Land and Titles Act 2020, s 64. Notably, the Land and Titles Bill 2020 retained this role for solicitors; it is unclear why it has been removed.

259 Land and Titles Act 2020, s 64.

260 Section 46(2).

261 Corrin, above n 10, at 212.
} 
of the Court, which has struggled to keep up with its case load. ${ }^{262}$ While the Acts do include time limits for judicial decision-making, they do nothing to resolve practical resourcing problems with the LTC which have slowed down the process to date. To the contrary, the Samoa Law Society has argued that the new appellate structure will increase the Court's caseload due to a litigation culture favouring appeals. $^{263}$

In addition, the Acts do not address issues with the capacity and skills of LTC judges identified in the 2016 Special Inquiry. ${ }^{264}$ It is not clear that there are enough experienced Samoan legal practitioners with matai titles to staff three courts, as the CAA requires (previously, LTC judges only needed to have been involved in "the administration of justice" for five years). ${ }^{265}$ Also unusual is the reliance on "retired Supreme Court judges" to fill positions on the Court of Appeal, ${ }^{266}$ the Judicial Service Commission, ${ }^{267}$ and the LTCAR (the last of which requires Samoan ethnicity). ${ }^{268}$ During consultations, the Samoan judiciary indicated that there were only three retired Supreme Court judges in Samoa who met the criteria under the CAA: one is now a member of parliament, one currently sits in the High Court of Nauru and the third has not worked in 30 years. ${ }^{269}$

In conclusion, while the three Acts obtain a symbolic victory for custom by removing the Supreme Court's supervision over the LTC, it is not clear that they strengthen the practical capacity of Samoan citizens to enforce their customary rights.

\section{RESOLVING THE TENSION}

In considering these Acts, it is instructive to return to the division between "strong" and "weak" legal pluralism. ${ }^{270}$ The CAA's desire to "adopt the best of both the modern principles and the customary values" suggests a commitment to strong pluralism, ${ }^{271}$ by recognising multiple valid sources of legal obligation operating independently of each other. ${ }^{272}$ In theory, the bifurcation of the court hierarchy is consistent with this, with validity of customary jurisprudence no longer dependent

262 At 212

263 Samoa Observer, above n 255, at 00:02:00-00:02:30.

264 Special Inquiry Report, above n 47, at 21-23 and 36.

265 Land and Titles Act 1981 (repealed), s 26A(2)(a); but see Constitution Amendment Act, s 7 art 104D(1)(a).

266 Constitution Amendment Act, s 4, inserting art 73(2)(c).

267 Section 4, inserting art 79(1)(e).

268 Section 7, inserting art $104 \mathrm{C}(2)(\mathrm{a})$.

269 Feagaimaali'i, above n 82, at [38].

270 Griffiths, above n 38, at 289.

271 Constitution Amendment Bill 2020 (explanatory memorandum) at [1.6].

272 Woodman, above n 41, at 39 . 
on Supreme Court oversight. Nonetheless, the LTC hierarchy is not entirely autonomous, with the bounds of what constitutes enforceable custom in Samoa still drawn by the Constitution. ${ }^{273}$ Further, the removal of the Supreme Court's judicial review function has resulted in similar procedures being directly imported into the customary system. Indeed, the LTCAR's judicial review functions appear to materially increase potential interference of common-law concepts in customary matters. ${ }^{274}$ This is particularly so given that a minimum of one Supreme Court judge will sit on the LTCAR, ${ }^{275}$ despite the CAA's goal of removing Supreme Court involvement in customary matters. This is not to suggest that Samoan custom can never change or develop. Rather, the procedural reforms in the LTC hierarchy and the introduction of a judicial guidance clause demonstrate that Samoa's plural systems of law cannot be entirely separated: there are inevitable overlaps and conflicts to be resolved. Recognising, as Corrin suggests, that there is "still a vast divide between common law and customary cultures", then, the 2020 reforms fail to bridge this gap while simultaneously introducing new challenges. ${ }^{276}$

This is not to discredit Mulitalo's concerns about the potential for constitutional and common law supremacy to weaken customary systems. ${ }^{277}$ Ironically, the draft judicial guidance clause in the Constitution Amendment Bill 2020, although lacking specificity, ${ }^{278}$ would be a robust starting point to entrench custom into the legal system. That clause required systematic consideration of relevant customs in all cases, ${ }^{279}$ whereas the amended clause leaves consideration of custom to judicial discretion. ${ }^{280}$ Future reform could focus on providing more specific guidance as to when courts should look to custom. Papua New Guinea's Underlying Law Act 2000 provides a useful comparison. ${ }^{281}$ Although Corrin notes several problems with the Act, it attempts to build a local jurisprudence by giving detailed guidelines as to where custom must be applied. ${ }^{282}$ Solomon Islands ${ }^{283}$ and Nauru ${ }^{284}$ provide similar, albeit less detailed, hierarchical approaches which give custom higher status than the

273 Constitution Amendment Act, s 7, inserting art 104A(5)(a)-(b).

274 Section 7, inserting art 104C(5)-(7).

275 Section 7, inserting art $104 \mathrm{C}(2)$

276 Corrin, above $\mathrm{n} 74$, at 331 .

277 Mulitalo, above n 6, at 25-26.

278 Constitution Amendment Bill 2020, cl 4, amending art 72.

279 Clause 4, amending art 72.

280 Constitution Amendment Act, s 4, amending art 71.

281 Underlying Law Act 2000 (PNG).

282 See especially Jennifer Corrin "Getting down to business: developing the underlying law in Papua New Guinea" (2014) 46(2) Journal of Legal Pluralism and Unofficial Law 155 at 160-161.

283 Constitution of Solomon Islands 1978, sch 3 para 3(2).

284 Customs and Adopted Law Act 1971 (Nauru) s 3. 
common law. Palau's Constitution is more unusual, stating that in cases of conflict between statute and traditional law, "the statute shall prevail only to the extent it is not in conflict with the underlying principles of the traditional law". ${ }^{285}$ This has allowed the Supreme Court of Palau to establish a more systematic and wide-ranging consideration of custom, with the case of Beouch v Sasao setting out clear principles for how to plead and prove Palauan customary law. ${ }^{286}$ Noting the conservatism of Samoan courts, ${ }^{287}$ however, legislative specificity should be preferred above ambiguity to entrench a role for custom.

On a broader level, this clash highlights perceived inconsistencies between human rights and Samoan custom, which human rights advocates should consider when envisioning future reforms. As already noted, several writers identify mutuality, respect, dignity, equality and protection as core communal Samoan values which are consistent with individual rights. ${ }^{288}$ Recognising this, the NZLC proposes a strategy of "harmonisation" to promote human rights in Pacific societies, which focuses on essential values rather than specific customary practices and uses these values to demonstrate points of compatibility. ${ }^{289}$ This process works in both directions, however. As Mulitalo proposes, judges and lawyers trained in the common law will benefit from professional development focused on identifying and applying custom, so they too can identify points of crossover between the different systems. ${ }^{290}$ This will serve to counter underlying assumptions of state or common law supremacy.

Further, although this article has criticised the proposal that different courts should administer separate interpretations of fundamental rights, the CAA's core idea of interpreting fundamental rights more from a customary perspective provides a useful starting point for constitutional reform. Within the Constitution, the strict structural division between provisions concerning fundamental rights and custom is a genuine barrier to harmonisation. ${ }^{291}$ Multiple Pacific jurisdictions carve out limited customary exceptions to constitutional human rights provisions to address this. ${ }^{292}$ Article 8 of the Samoan Constitution includes an exception to the right against forced labour to preserve communal service responsibilities under the matai system. ${ }^{293}$ Broader examples include the constitution of

285 Constitution of the Republic of Palau 1979, art V s 2.

286 Beouch v Sasao [2013] PWSC 1 at 9-14.

287 Angelo, above n 2, at 164-165.

288 Huffer and So'o, above n 81, at 312; and Vaa, above n 95, at 241-243.

289 Converging Currents, above n 42, at 75 .

290 Mulitalo, above n 6, at 133

291 See Samoan Constitution, preamble, pt II and pt IX.

292 See Constitution of the Independent State of Papua New Guinea art 53(5)(d); and Constitution of Solomon Islands 1978 art $15(5)(d)$

293 Samoan Constitution, art 8(2)(d). 
Tuvalu, which includes a customary exception to the freedom against discrimination; ${ }^{294}$ and the constitution of the Marshall Islands, which create a wide exception to its Bill of Rights for matters relating to customary land tenure. ${ }^{295}$ As already noted, specificity should be favoured in constructing exceptions. Tuvalu's exceptions have been criticised for vagueness, leading to cases where custom has prevailed in the face of overt gender and religious discrimination. ${ }^{296}$ However, 2010 amendments to the Tuvaluan constitution have sought to address this by subjecting customary practices to tests of whether they are "harsh, oppressive or otherwise unlawful", 297 or alternatively "reasonably justifiable in a democratic society". ${ }^{298}$ There is no reason why well-drafted exceptions targeted to resolve specific points of tension are not workable, with the United Nations noting that human rights should adapt to the local context. ${ }^{299}$ The Samoan Human Rights Institute proposes one such reform, suggesting a village fono's reasonable concerns about local order could be taken into account (without always being determinative) in religious freedom cases. ${ }^{300}$ Ultimately, reform should seek to promote a sense of Samoan "ownership" over Samoan law, while avoiding "a contest between custom and human rights when both are plainly important and bring satisfaction to large numbers of people".301

\section{CONCLUSION}

The 2020 LTC reforms have become a flashpoint for numerous political fault-lines in Samoa. This article has isolated one of these fault-lines, contextualising the 2020 legislation within longer-running debates about how to balance custom with state law in postcolonial jurisdictions. Underlying the debates is a key conceptual disagreement: must a greater role for custom come at the expense of fundamental human rights and the rule of law? The proposed solution, however - bifurcating the court system into two hierarchies, each administering its own conception of fundamental rights - is an impractical and problematic way of addressing this legitimate legislative challenge. The implications of the proposal for legal coherence and the workload of an already under-resourced court are, as I have demonstrated, concerning. More broadly, the changes formalise perceived inconsistencies

294 Constitution of Tuvalu 1986, art 27(7).

295 Constitution of the Republic of Marshall Islands, art X, s 1(1).

296 Sue Farran "Is Legal Pluralism an obstacle to Human Rights? Considerations from the South Pacific" (2006) 38(52) Journal of Legal Pluralism and Unofficial Law at 77-105; and Dejo Olowu "When Unwritten Customary Authority Overrides the Legal Effect of Constitutional Rights: A Critical Review of the Tuvaluan Decision in Mase Teonea v Pule O Kaupule \& Another" (2005) 9(2) Journal of South Pacific Law.

297 Constitution of Tuvalu 1986, art 12(2).

298 Article 15.

299 International Council of Human Rights Policy Taking Duties Seriously: Individual Duties in International Human Rights Law - A Commentary (Versoix, 1999) at 24-25.

300 Ombudsman's Submission, above n 93, at 9-10.

301 Converging Currents, above n 42, at 211. 
between law and custom. The irony of this debate, however, is illustrated in the following quote from Sapolu $\mathrm{J}$ about religious freedom, which shows that customary values and individual rights need not be in tension: ${ }^{302}$

One must learn to tolerate and respect the religious beliefs of others even though such beliefs may be different from one's own religious beliefs. In this way peace, harmony and stability will remain and continue in village societies. ... History has also shown that the persecution of people because of their religious beliefs ... only resulted in immense and undesirable misery, hardship and suffering.

My focus on human rights and customary law in this article is not intended to detract from fundamental issues with the Acts discussed elsewhere, particularly in relation to judicial independence and the rule of law. The HRPP's loss of support in the 2021 election after 40 years of government speaks to the negative implications certain parts of the Acts have for Samoan democracy and good governance. Importantly, however, robust critiques of the 2020 reforms must not ignore that the LTC remains a source of public dissatisfaction in need of reform, and that seeking to clarify the role of Samoan customary law is not an inherently flawed goal. To this end, I have tried to draw attention to limited, practical proposals in the Acts which may improve the administration of law and custom in Samoa. These include stronger procedural safeguards in the LTCs to improve satisfaction with court outcomes, as well as the introduction of a judicial guidance clause (drafting aside) to expressly allow judges to consider customary practice and principle. These changes should be used as a starting point for alternative reform that seeks to entrench a clear role for custom without undermining democracy and the rule of law. Such reform will not be simple and should involve careful consultation with the diverse interest groups within Samoa that will be affected. However, a sensitive approach to Samoa's diverse and unique legal pluralist tradition, demonstrated repeatedly since independence, will ensure it continues to develop well into the future.

302 Lafaialii v Attorney General, above n 217, at [14] (emphasis added). 